\title{
OBITUARIES
}

\section{Dr. Roy Chapman Andrews}

Dr. Roy Chapman Andrews, famous for his Gobi Desert discoveries in the early 1920's, died in New York early in March. He was seventy-six. He was born at Beloit, Wisconsin, on January 26, 1884, and was educated at the comparatively small College there, graduating A.B. in 1906. He then proceeded to Columbia, where he took his A.M. degree in 1913. He also had some experience in the Museum of Comparative Zoology at Harvard. His later education was interrupted by his absences on expeditions, those forays and excursions, often with important scientific and geographical results, that were to be the main interest of his life and the foundations of his undoubted eminence.

His association with the American Museum of Natural History began in 1908 when he joined an expedition to Alaska; he did exploration work on the St. Lawrence in 1909, shortly afterwards becoming naturalist in the U.S.S. Albatross, which visited the Dutch East Indies and Borneo in 1909-10. During 1911 and 1912 he was in Korea and in 1913 he was back in Alaska. These were, however, but preludes to his main task, which came when, in 1916, he was appointed leader of the American Museum expeditions to Central Asia. From 1917 until 1931 he was intermittently in Mongolia and in China in pursuit of vertebrate fossils and the remains of man.

His chief, the distinguished director of the Museum, Prof. Henry Fairfield Osborn, hold the theory that the likely area of the dispersal of mammals and of man was to be found in the Orient, and the expedition's results, if not exactly convineing for this theory, were encouraging in the considerable materials that they produced. Dinosaurs and dinosaurs' eggs earned the expedition fame, though the dinosaurs were not so important as many that had already been found, and dinosaurs' eggs had been discovered earlier in England and in Franee. Andrews also found small Cretaceous mammals and giant Tertiary mammals and mastodons, but not a scrap of the fossil man he was working for, though Sinanthropus was later to turn up not so very far from the house where he kept palæontological court in Pekin.

Judged by any standards, Andrews's Asiatic expeditions were a success, and resulted in considerable additions to many museums other than his own, for the American Museum was generous, and excellent representatives of the dinosaurs from the expeditions are in the British Museum (Natural History).

Scientific and other honours rightly came to him. $\mathrm{He}$ was made Sc.D. of both his native Beloit and of Brown University, Rhode Island. He also received many medals, mainly for the geographical aspect of his work, from the National Geographic Society and the Explorers' Club in his own country, and from the national geographical societies of Sweden and Hungary.

During 1931-35 Andrews was vico-director in charge of exploration and research at the American Museum of Natural History, and from 1935 until 1942 he was director. He retired in 1942 with the title of honorary director.
He was the author of ten books and many scientific papers. Most of these were written in his beautiful homes in Connecticut or in California, where successively he lived after his retirement. But they were far from being his only interests. The Boy Scout movement and many sports, mostly connected with horses, engaged his attention, and he was always a hospitable man.

His name will be remembered in the annals of vertebrate palreontology and in the history of the distinguished Museum he served so well for so long.

W. E. SwINTON

\section{Mr. C. A. Shain}

Charles Alexander Shain, an outstanding member of the radio astronomy group at the Commonwealth Scientific and Industrial Research Organization (Australia) Radiophysics Laboratory in Sydney, died on February 11 at the early age of thirty-eight. His contribution to radio astronomy lay in the frequency-range around $20 \mathrm{Mc} / \mathrm{s}$. where he pioneered the study of the two foatures pectiliar to this range of radio astronomy : absorption in ionized interstellar hydrogen (H II regions), and absorption and refraction in the ionosphere. Observations in this frequency-range are particularly difficult owing to interference from radio stations and the complicating effects of the ionosphere ; but they give unique information of great importance to radio astronomy. Shain's work is basic in this field.

Shain studied physics in the University of $\mathrm{Mel}$ bourne and graduated in 1942. Ho immediately entered the second Australian Imperial Force, but was discharged on medical grounds late in 1943. He then joined the staff of the Radiophysics Laboratory, where he stayed until his death. During the remaining stages of the War, he worked on radar counter-measures, and from 1945 on various aspects of decametre-wave radio astronomy.

His work in radio astronomy began with a study of Moon echoes at a frequency of $20 \mathrm{Mc}$./s. This work, which was an immediate follow-up of the pioneering American and Hungarian experiments, led to the recognition of the dual causes of the fading of Moon echoes: libration of the Moon and propagation effects in the ionosphere. Using parts of the same equipment, he then began the observations of the distribution over the sky of relatively low-frequency (20-Mc./s.) cosmic radio waves which he continued until his death. He first used broadside arrays, the largest of which consisted of 30 half-wave dipoles and had a beam-width of $17^{\circ}$, and then a 'Mills cross' with arms 3,500 ft. long and a resolution of $1.4^{\circ}$.

In the first phase of these investigations he was able to show conclusively that the brightness distribution over the Milky Way at this frequency was markedly influenced by absorption in HII regions; but he had insufficient angular resolution to delineate even the largest of these regions, and his 'Mills cross' was designed to overcome this limitation. At the time of his death he had nearly completed a 19 . Mc./s. map of the greater part of the Milky Way, which shows numerous examples of the obscuring 
regions which he sought. His colleagues plan to complete and publish this unique and important work as soon as practicable.

In this frequency-range, the absorption of cosmic radio-waves in passing through the ionosphere is often appreciable and the interpretation of cosmic observations requires a knowledge of absorption in the various ionospheric layers. Shain's pioneering work on such absorption, particularly interesting at the time of solar flares, sufficed for his own purposes and has since given rise to a vigorous branch of ionospheric research which follows the inverse approach and uses observa. tions of the absorption of cosmic radio waves to obtain information about phenomena in the ionosphere.

A by-product of the cosmic radio wave studies concerns radio emission from Jupiter. Following the discovery in the United States in 1956 of emission from this planet in the $20-\mathrm{Mc}$./s. range, Shain examined his old records. He found a large number of extended bursts of emission, which had previously been attributed to terrestrial interference, but which could now be identified with reasonable certainty as due to emission from Jupiter. Examination of the times of occurrence of these bursts showed a remarkable correlation with the rotation period of Jupiter, indicating that the emission originated in a very few active areas on the planet which remained in fixed positions for long periods.

Alex. Shain was a wonderful colleague in the laboratory-imaginative, well balanced, exceedingly unselfish, and a real friend to all. In his home community he was a leader in Church affairs. In murra where he lived he was, among other things, the Anglican Church in the Sydney suburb of TurraSunday school superintendent, lay reader and the leader of a Bible Study Group. He was a man who exemplified the principles of Christianity in all his dealings with men.

J. L. Pawsey

\section{Mr. K. J. F. Park}

Tre death of Kenneth John Frederick Park in a drowning accident on March 2 at the age of thirty-two has robbed the Nature Conservancy of a most valued officer, science of a first-rate ecologist and the world of a man of rare quality.

Park was educated at the Royal Grammar School, Newcastle upon Tyne, and at King's College, Newcastle. Between school and college he served three years in the Royal Air Force, and this took him to the Middle East and gave width of experience to an alert mind. He left the University with a first-elass degree in botany and a good knowledge of the aretic-alpine vegetation of northern England, the Scottish Highlands and the Hebrides. His interest in field botany led him to postgraduate work on the ecology of Upper Teesdale, particularly the sugar-limestone outcrops. This work was interrupted in 1954 by his appointment as officer-in-charge of the Nature Conservancy's Moor House Field Station more than 1,800 ft. above sealevel in the northern Pennines.

His basic seientific interest was the conservation of upland Britain, using the word conservation in a wide and humanitarian sense. His own research was focused on the potential productivity of the grasslands on mineral soils. He aimed to get quantitative data on long-term trends in fertility-levels, as determined by grazing, leaching. soil weathering and other factors eausing gain or loss of nutrients. During the past year or two he had been attacking these problems directly, for example by observations on rates of leaching, but before this he had put in much intensive work on recording the existing state of the various grassland types on the Nature Reserve. He did this by setting up a series of sheep exclosures and using various methods of mapping, point-quadrat recording, and detailed photography of vegetation. The methods were not of course original, but the standard of accuracy and the finish of the work are altogether outstanding and are witnessed in the volumes of the Nature Reserve Record Book. The plots have been laid out and recorded as the firm starting-point for observations visualized as going on over a century or more.

Over and above his own research line, he built up an impressive collection of information about the Reserve and the surrounding countryside, and himself contributed many superb photographs.

When he went to the Field Station he had nothing to work on but rather sketchy possibilities; but in his six years of imaginative and efficient management. he created a live centre of scientific work in remote and difficult conditions, where visiting workers could come and use their time productively. His achievement was due not only to his very hard work and exceptionally high standards but even more to his personal qualities, which enlisted the co-operation of anyone who came into contact with him, and the devoted loyalty of all his colleagues, both senior and junior.

\section{Dr. Paul Haas}

Paul HaAs, who died on April 6 at Cheam, was born in 1877, the son of distinguished parents. His father was professor of Sanscrit at University College, London, and his mother was a gifted pianist who, before her marriage, had a European reputation as a soloist. Even in her old age, Madam Haas played the music of Bach in a manner few could equal, and her son inherited musical appreciation.

Paul Haas was educated at University College School when it was in Gower Street, then at University College, and he studied also both at Freiburg and Geneva. As an investigator, he was very deliberate and conscientious. With the late Prof. T. G. Hill, he collaborated in the investigation of the biochemistry of seaweeds and the chromogens of Mercurialis perennis, and they produced, in 1913, "An Introduction to the Chemistry of Plant Products", which was afterwards extended into a two-volume work.

It was in teaching, however, that Haas found his chief interests, and his lectures and demonstrations were always carefully prepared. $\mathrm{He}$ lectured on organic chemistry both at St. Mary's and St. Thomas's Hospital Medical Schools, and also at the Royal Botanic Gardens, Kew, until he became reader in plant chemistry at University College, of which he was a Fellow.

Paul Haas had a retiring kindly personality with a quiet sense of humour. He looked after his mother devotedly, at their home in Westbourne Park, until her death, and his colleagues had regarded him as a confirmed bachelor. But romance came to him when inspecting schools for the University of London, and at the age of sixty-one he married Beryl Grace Wood who, with a son of the marriage, survives him.
E. J. Salisbury 